\title{
Building Firesafety Design against a Large Earthquake-Based on the 1995 Kobe-Hanshin Earthquake
}

\author{
SHIN'ICHI SUGAHARA \\ Department of Architecture \\ Faculty of Engineering \\ The University of Tokyo \\ 7-3-1 Hongo, Bunkyo-ku, Tokyo 113, Japan
}

\begin{abstract}
The Kobe-Hanshin Earthquake was the world-first seismic desaster with about 6,050 victims and 40 group fires basically caused by the collapse of about 46,000 lowrise and 3,000 middle or high rise buildings, which occurred in the midst of mordern technological urban areas. Destroyed highway and jammed up main roads made supporting fire engines unable to access fire sites. City fire hydrants were almost ineffective, because their piping systems was broken. This paper shows the outline of fire disasters and implements a concept on the limitation of group fire by constructing urban fire compartment. The author indicates the compartmentation must be mostly composed of improved aged-houses and buildings, because remodelling of inhabited district is quite hard. And the results of investigations warned that highly damaged fire equipments and facilities revealed the fire safety of building itself quite serious in a large earthquake. Through various studies,several important countermeasures are proposed in this paper.
\end{abstract}

KEYWORDS:the Kobe-Hanshin earthquake, cause of fire outbreak, group fire, urban fire compartment,damage of fire equipment,buil.'ing firesafety design,cyberspace 


\section{INTRODUCTION}

The Kobe-Hanshin earthquake was one of the greatest lessons for civil engineering and architectural technologies in urban areas. In Japan,this earthquake is generally called 'The '96 Hyogoken Nambu Earthquake' in seismological or meteorological field and also 'The Great Hanshin-Awazi Earthquake' in sociological, psychological or political field. However,in abroad,'The Kobe Earthquake' or 'The Kobe-Hanshin Earthquake' has been more common. Hanshin is called as the districts developing from Osaka to Kobe, and Awazi Island where many raditional houses collapsed lies offshore about $10 \mathrm{~km}$ south-west of Kobe. Human or property damages concentrated mainly seashore area in Kobe, and especially in her western part,a great amount of aged houses destroyed and thousands of people were killed in sleep. Group fire and numbers of deaths mainly occurred in those areas. The purpose of this paper is to descrive the facts on this earthquake damages especially focused on fire disaster, and to search effective methods for firesafety countermeasures. The quake was 5:46:52,17 Jan.,' 95 .

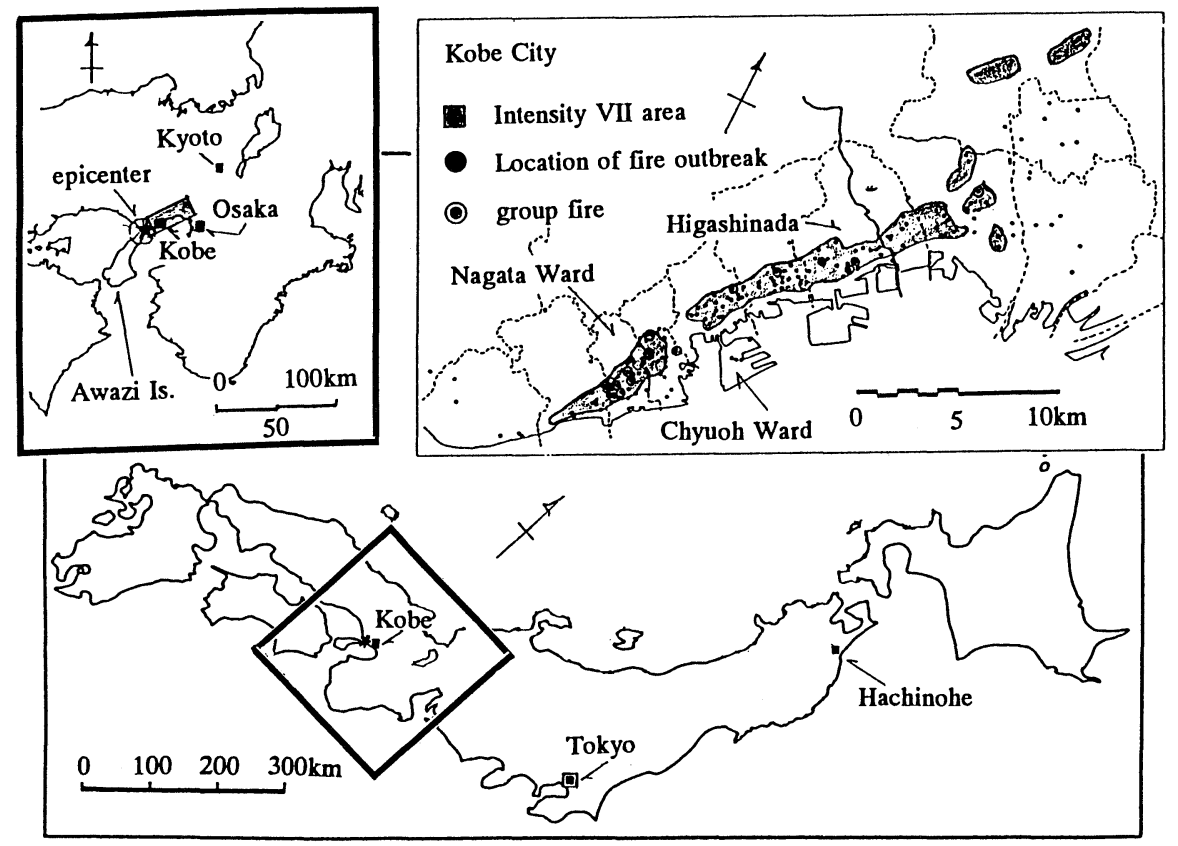

FIGURE 1. The location of epicenter and the distribution of seismic intensity VII and fire origins 


\section{OUTLINE OF THE KOBE-HANSHIN EARTHQUAKE}

\section{1) The strong seismic motion}

The Kobe-Hanshin Earthquake was the world-first strong intraplate earthquake that hit directly the centrum of a modern developed city.The distribution of epicenters of main shocks concentrated around $34 \cdot 36.4$ ' $\mathrm{N}, 135 \cdot 2.6$ 'E where locate offshore along Nojima fault systems between Kobe and Awazi Is. as shown in FIGURE 1.According to the Japan Meteorological Agency(JMA)Kobe Obsevatory, the depths of the shocks are around 10km. The magnitude was 7.2 on the Richter scale.The maximum peak acceleration $818 \mathrm{gal}$ in the NorthSouth direction and 332gal in the Up-Down direction were recorded respectively, And in several places, the value of U-D motion was greater than that of hori-zontal motion.For example, vertical 507gal - horizontal 319gal at Takenaka corpolation ob-sevatory and vertical 367gal-horizontal 300gal at Kobe university basement obsevatory. Thedistribution of seismic intensity VII is also shown in FIGURE 1[1]. The intensity VII 'ruin-ous' is determined by the JMA on the lessons at the Fukui earthquake in 1948[note.1].In this connection,the intensity VI 'disastrous' was recorded in Toky' district at the GreatKanto Earthquake in 1923 [note.2].

\section{[note.1]}

Fukui Earthquake; [Time] 16:13,June 28,1948, [Location] Fukui city, 120km NNE from Kyoto,Japan, [Seismic intensity] M7.3, intraplate quake,(VII), [Damage] fatalities 3,769 (including burnt \& other causes 937, polulation 84,820), burnt houses 2,410 (area 59.62 ha),[Weather] cloudy, avg. wind speed $2.1 \mathrm{~m} / \mathrm{s}$.

[note.2]

The Great Kantoh Earthquake; [Time] 11:58, Sep.,1923, [Location] around Tokyo and Yokohama,Japan, [Seismic Intensity] M7.9, interplate quake,Tokyo VI,[Damage] fatalities 99,331(almost burnt to death,households 397,000),burnt houses 219,000 (area about 36ha),[Weather] cloudy, wind speed $11 \sim 15 \mathrm{~m} / \mathrm{s}$.

\section{2) Human Damages}

Approximately 4,950 fatalities occurred by the destruction of aged wood houses. From the autoptical point of view, about 550 victims were burnt to death in their collapsed houses[2]. About $70 \%$ of deaths occurred in Kobe City, especially at both the eastern and the western part of the city[3].In addition, it is also quite important thatabout 600 peoples were dead by posttraumatic stress disorder or lack of enough medical cares after the earthquake[4][5], which means total fatalities caused by the Kobe earthquake should be recognized to reach approximately 6,100[6].Fatalities in past earthquakes are recorded as shown in TABLE 1. 
TABLE 1. Fatalities in recent earthquake

\begin{tabular}{|c|c|c|c|c|c|c|}
\hline earthquake & date & intensity & deaths & destroyed & burnt & remarks \\
\hline Mexico & $\begin{array}{c}\text { 7:17:44 } \\
\text { Sep.,20,1986 } \\
\end{array}$ & $\begin{array}{l}\text { M8.1 } \\
\text { Richter V }\end{array}$ & $\begin{array}{l}5,000(\mathrm{miss} \\
- \text { ing: } 2,000) \\
\end{array}$ & $\begin{array}{r}954(\text { big dam } \\
- \text { aged } 2,296 \text { ) } \\
\end{array}$ & $\begin{array}{l}351 \text { (for } \\
3 \text { days) } \\
\end{array}$ & $\begin{array}{l}\text { epicenter is } \\
400 \mathrm{~km} \mathrm{far}\end{array}$ \\
\hline $\begin{array}{l}\text { Loma } \\
\text { Prieta }\end{array}$ & $\begin{array}{c}17: 04 \\
\text { Oct.,17,1989 } \\
\end{array}$ & M7.1 & $\begin{array}{l}\text { 61(freeway } \\
41 \text { ) }\end{array}$ & $\begin{array}{l}40(\text { Santa } \mathrm{Cu} \\
- \text { ruse) } \\
\end{array}$ & $\begin{array}{l}25 \text { (St. } \\
\text { Curuse) }\end{array}$ & $\begin{array}{l}\text { collapse at } \\
\text { crawl space }\end{array}$ \\
\hline $\begin{array}{l}\text { Hokkaido } \\
\text { Nanseioki } \\
\text { SW }\end{array}$ & $\begin{array}{l}22: 17 \\
\text { July, } 12,1993\end{array}$ & $\begin{array}{l}\text { M7.8 } \\
\text { RichterVI } \\
\text { (okushiri) }\end{array}$ & $\begin{array}{l}\text { 202(fire 2) } \\
\text { missing } 29\end{array}$ & $\begin{array}{l}594 \text {,heavy } \\
400\end{array}$ & $\begin{array}{l}189 \\
\text { (house } \\
107)\end{array}$ & $\begin{array}{l}\text { Quake,Tsunami, } \\
\text { | Fire }\end{array}$ \\
\hline $\begin{array}{l}\text { North- } \\
\text { ridge }\end{array}$ & $\begin{array}{l}4: 31 \\
\text { Jan.,17,1994 }\end{array}$ & $\begin{array}{l}\text { M6.7, } \\
\text { intraplate }\end{array}$ & 57 & $\begin{array}{l}62,285 \text { (un- } \\
\text { safe } 2041 \text { ) }\end{array}$ & 104 & $\begin{array}{l}\text { garage destroy } \\
\text { mobile hm fire }\end{array}$ \\
\hline
\end{tabular}

\section{3) Houses and Building Damages}

Building Research Institute(BRI) reported finally that the numbers of buildings damaged in various features are shown in TABLE 2 by using Geographical Information System(GIS)[7]. The table indicates that the rate of destroyed one or two storied buildings was $9.4 \%(46,022)$ in comparison with more than three storied buildings of $6.4 \%(3,081)$. The total rate of damaged buildings is estimated $87.46 \%(489,276)$ for lowrise and $8.67 \%(48,519)$ for more than three storied buildings.Several characteristic features were seen in the collapse of traditional houses with lack of structural soundness for seismic motion as shown in FIGURE 2, decay of wood strucural members and heavyweight of roof tiles called 'Kawara' in Japanese, and the collapse of middle story of middle-rise buildings,because the seismic motion was amplified there, structural materials and/or components was changed just at that story and so on. TABLE 3 shows a brief histrory of legal revision on wood structure in Japan.It seems that the rate of non-damaged houses linearly increased along with their aging as shoun in FIGURE 3 [16].

TABLE 2. The number and rate of damaged buildings and houses in Hanshin-Awazi earthquake

\begin{tabular}{l|c|c|c|c|c|c|r}
\hline building & destroyed & damaged & slight damage & no damage & burnt & no investigation & total \\
\hline$<=2$ FLs & 46,022 & 42,208 & 107,887 & 192,765 & 4,368 & 96,026 & 489,276 \\
& $(9.4)$ & $(8.6)$ & $(22.1)$ & $(39.4)$ & $(0.9)$ & $(19.6)$ & $(100)$ \\
\hline$>=3$ FLs & 3,081 & 3,273 & 9,035 & 27,794 & 463 & 4,873 & 48,519 \\
& $(6.4)$ & $(6.7)$ & $(18.6)$ & $(57.3)$ & $(1.0)$ & $(10.0)$ & $(100)$ \\
\hline
\end{tabular}


TABLE 3. A brief history of legal revision of wood structure

\begin{tabular}{l|c|l}
\hline $\begin{array}{l}\text { Regulation } \\
\text { technical } \\
\text { ordinance } \\
\text { in Urban } \\
\text { Bldg Law }\end{array}$ & 1924 & $\begin{array}{l}\text { Outline of revision } \\
\text { brace as must }\end{array}$ \\
\hline $\begin{array}{l}\text { Bylaw of } \\
\text { Bldg Std } \\
\text { Law }\end{array}$ & 1950 & $\begin{array}{l}\text { quality of timber } \\
\text { double bracing } \\
\text { quantity of walls }\end{array}$ \\
\cline { 2 - 3 } & 1971 & $\begin{array}{l}\text { RC base beam } \\
\lambda>=150 \text { against buckling } \\
\text { anti-decay policy }\end{array}$ \\
\hline $\begin{array}{l}\text { Ordinance } \\
\text { of Minister }\end{array}$ & 1982 & $\begin{array}{l}\text { induction of timber } \\
\text { frame construction }\end{array}$ \\
\hline
\end{tabular}

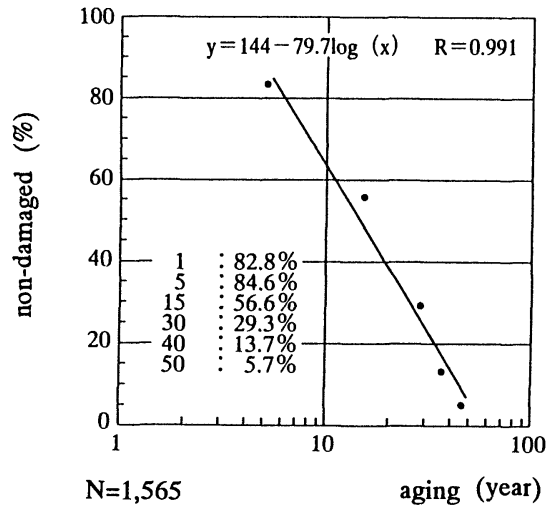

FIGURE 3.Relation between non-damaged ratio and aging of small houses

\section{FACTS ON EARTHQUAKE FIRE DAMAGES}

\section{1) The number of fire occurrences,burnt buildings and houses}

The number of fire occurrences is shown in TABLE 4[8][9], among of which 204 occurred in the same day as the quake outbreak,95 occurred just within 6 minutes after the quake, 69 during $6 \sim 9$ am,19 during 9am $\sim$ noon, and 21 during noon $\sim 12 \mathrm{pm}$. Fire occurred even for 7 days after 17th January,1995.This indicates the main cause of fire outbreakes was ignition of dispersed timbers, household goods or leaked town gases by sparking recovered erectricity[10]. The distribution of fire origins were homogeneously dispersed within seismic intensity VII areas as shown in FIGURE 1[9][11]. However,determination of the number of fire outbreaks is difficult,because of various confusions during serious motions. The number of burnt down houses was 7,119, among of which7,046(99.0\%) belonged to the cityof Kobe [5], and as for buildings 4,368 were blazed up including 4,288 (98.2\%) in Kobe[7].

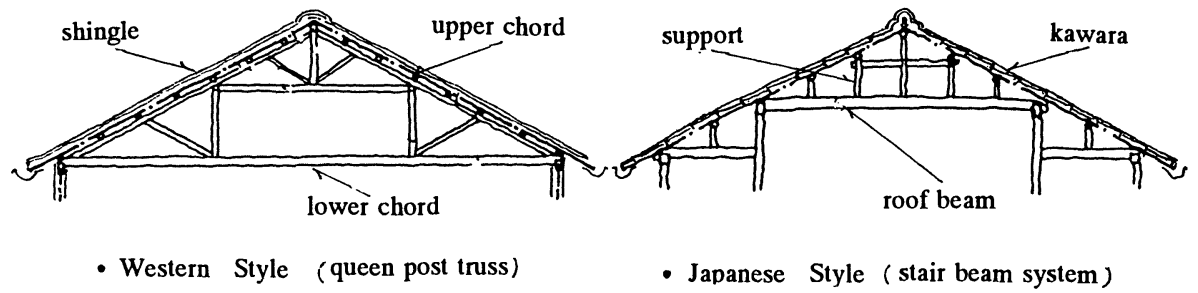

FIGURE 2. Difference of roof structure between Japanese and western style 
TABLE 4. The number of fire-outbreaks along with lapse of time

\begin{tabular}{|c|c|c|c|c|c|c|c|c|c|c|c|}
\hline area,(intensity) & \multicolumn{5}{|c|}{ Jan.17 } & total & 18 & 19 & 20 & $21 \sim 26$ & 27 \\
\hline Kobe city,(VI,VII) & $\sim 6 \mathrm{am}$ & $6 \sim$ & $7 \sim$ & $8 \sim$ & $9 \sim$ & 109 & 14 & 15 & 8 & 29 & 0 \\
\hline Higashinada & 9 & 1 & 1 & 3 & 3 & 17 & 2 & 4 & 1 & 4 & \\
\hline Chyuoh & 6 & 4 & 3 & 2 & 5 & 20 & 3 & 3 & 3 & 6 & \\
\hline Nagata & 12 & 1 & 0 & 0 & 4 & 17 & 1 & 4 & 2 & 3 & \\
\hline Others--6wards & 27 & 4 & 1 & 6 & 17 & 55 & 8 & 4 & 2 & 16 & ( \\
\hline Osaka City,(IV,V) & - & - & - & - & - & 16 & 2 & 2 & 3 & 12 & \\
\hline Takarazuka,(V,VI) & - & - & - & - & - & 4 & 0 & 0 & 2 & 3 & \\
\hline
\end{tabular}

\section{2) The occurrence of group fire and formation of fire barriers}

Group fires were mainly caused by the collapse of houses which formed continuous piles of broken wood fuels to make a bridge for spreading fire across road,and also caused by flaming up of markets with above-road combustible arcades, of chemical shoes-factories with much amount of both plastics and flammable adhesives, and shortage of firefighting water [11][12]. The number of conflagrations burnt over $33,000 \mathrm{~m}^{2}$ was 5 ,group fires over 10,000 $\mathrm{m}^{2}$ was 14 ,and fires burnt over $3,300 \mathrm{~m}^{2}$ was $21[11][12]$. These group fires were mostly concentrated in pre-adjusted densely inhabited districts where there exist narrow paths less than $4 \mathrm{~m}$ in width and collapsed old houses or tenements constructed over 50 years before, and these factors made an easiness to grow up fire by radiation or flying brands.Fortunately, when the earthquake occurred,wind speed was less than $4 \mathrm{~m} / \mathrm{s}$, and the rate of fire spread was not accelerated. The average speed of group fire spreading was estimated approximately 20 $\sim 40 \mathrm{~m} / \mathrm{h}$ for leeward side at wind speed $1 \sim 3 \mathrm{~m} / \mathrm{s}$ and also $40 \sim 75 \mathrm{~m} / \mathrm{h}$ at $3 \sim 4 \mathrm{~m} / \mathrm{s}$. As for past large fires, the average spreading speed was recorded $100 \sim 150 \mathrm{~m} / \mathrm{h}$ at wind speed $10 \sim 12 \mathrm{~m} / \mathrm{s}$ in the Sakata city conflagration on 31 Oct.,1976 and also $200 \sim 300 \mathrm{~m} / \mathrm{h}$ at 8 $\mathrm{m} / \mathrm{s}$ in the Great Kanto Earthquake fire on 1 Sep.,1923[13]. In this situation, the ratio of barriers effective against fire spreading were generally $40 \%$ as of road, $23 \%$ each as of open space and fire protective buildings or houses, and $14 \%$ as of fire fighting activities[14].As for windows of houses which remained in safety around group fire areas, the ratio of each type of their glazings per lapse of time after construction are shown in FIGURE 5, and in case of houses whose claddings were considerably burnt, the ratio of remained mesh-wired glass, parallel-wired glass and regular glass were about $75 \%, 17 \%$ and $13 \%$ respectively as shown in FIGURE 6[15]. In non-fire areas with seismic intensity VII, the rate of windows whose houses were partly damaged were $68 \%$ as of non damaged,17\% as of deformed, $12 \%$ as of partially broken and $3 \%$ as of broken, and if windows were protected by wired glass, these houses could be saved from the fire[16]. FIGURE 4 is a example of fire sites[note.3]. 
The purpose of this investigation was to clarify the facts on the effectiveness of exterior housing materials exposed to grouped fire as shown in the above description and FIGURE 5,6. Features of the fire site shown in FIGURE 4 are as follows.

[location] Sumaura Dori 3-8,Suma ward,Kobe city//[fire outbreak]time;about 9:00am,17 Jan.,1995,duration;9:00am-12:00// [cause of fire] gas was leaked along with the destruction of houses, and the leaked gas seemed to be ignited by recovered service of erectricity//[burnt out areas]burnt out areas:489 $\mathrm{m}^{2}$,burnt down houses:11// [spread of fire] Old houses collapsed toward their southside road $4 \mathrm{~m}$ in width, and ignited by recovered gas. In the northside area,flames grown up in collapsed debris easily developed and extended through debris-bridges to the southside house.Fire engines could' nt work because of interruption of city water.Afterwards sea water was pumped up for fire fighting.// [escription of survived houses]

(1) 3 storied house: construction;1994,ceramic roof tile,ceramic cladding,polycarbonate sun room roof,shutter+wiredglass glazing.//(2) 2 storied warehouse (kura in Japanese), constructed about 20 years before,soil wall with wood waist cladding,ceramic roof tile (kawara in Japanese), no openings.//(3) 2 storied tenement, constructed about 30 years before,wood cladding,non-wired glazing, kawara roof./(4) 2 storied houses:constructed about 50 years before,metal panel cladding,kawara,non-wired glazing.

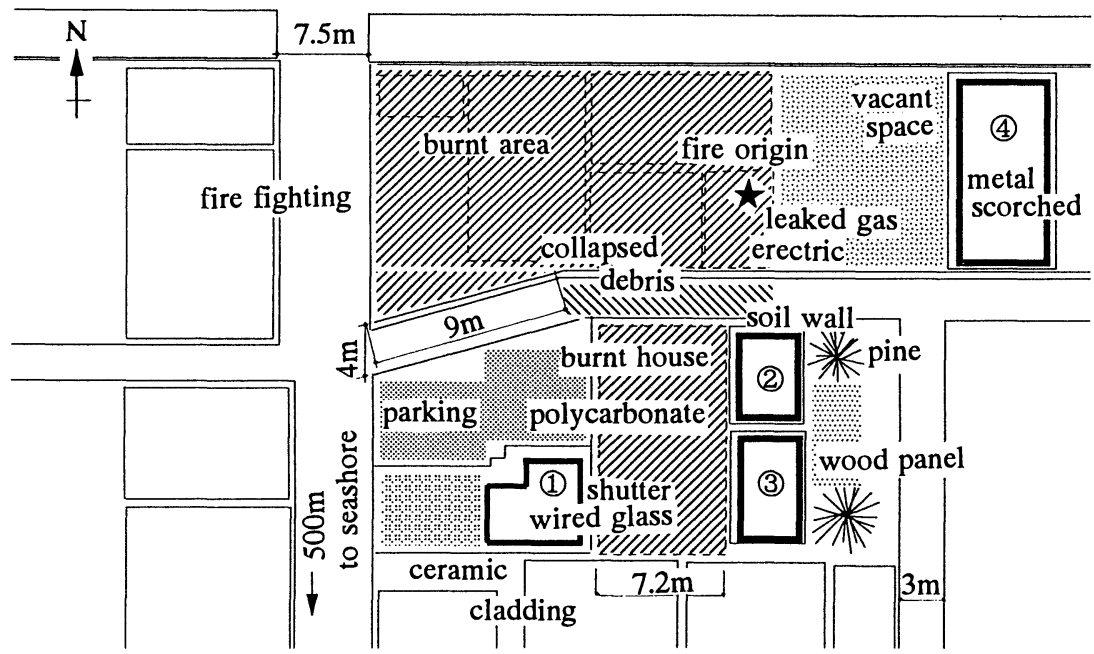

FIGURE 4. A exsample of ambient features at a grouped fire site 

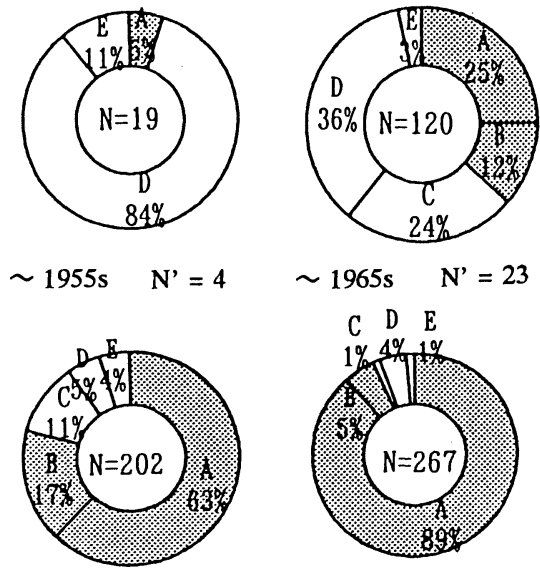

$\sim 1975 \mathrm{~s} \quad \mathrm{~N}^{\prime}=29$

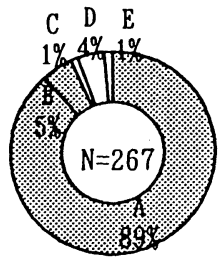

$1985 \mathrm{~s} \sim \mathrm{N}^{\prime}=26$

$N^{\prime}=$ number of buildings

FIGURE 5. Relation between type of glazings and age of survived houses around the ambit of group-fired areas

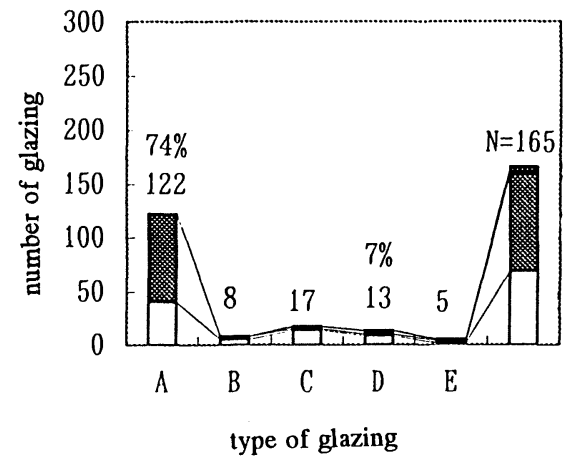

\section{A:mesh-wired glass}

C:palallel-wired

B:palallel-wired glass

D:regular glass

with sliding metal door

E:unknown

FIGURE 6. Relation between damage of glazings and burnt exterior claddings of survived houses around the left-mentioned areas

\section{3) Damages of fire facilities and equipments in buildings}

Fire equipments such as alarm,sprinkler,telecommunication,hydrant,and emergency generator were considerably damaged in the earthy':ake.In Kobe,there were 4,556 buildings which legally need to install sprinkler systems. Among of them, 544 sprinkler-installed buildings were investigated by the Kobe Fire Department. These floor areas were less than $1,000 \mathrm{~m}^{2}$ as of 19 bldgs, $1,000 \sim 3,000 \mathrm{~m}^{2}$ as of 98 bldgs,3,000 6,000 $\mathrm{m}^{2}$ as of 129 bldgs and more than $6,000 \mathrm{~m}^{2}$ as of 296 bldgs, and stories were less than 5 as of 273 bldgs, $6 \sim 10$ as of 172 bldgs, $11 \sim 15$ as of 58 bldgs, $16 \sim 20$ as of 7 bldgs and more than 21 as of 16 bldgs. The department reports as shown in TABLE 5 that the rate of damage of sprinkler systems was $40.8 \%$ (222/544 buildings) including $25.4 \%$ as of plumbing damage, $22.4 \%$ as of head and $13.8 \%$ as of water tank, and the rate of damage of automatic fire alarm systems was 20.1 $\%(109 / 542$ bldgs),and that of telecommunication systems was $12.8 \%$ (61/478 bldgs),that of emergency generator systems was $16 \%$ ( $71 / 444$ bldgs) including $9.2 \%$ as of fan, $8.1 \%$ as of fuel tank, $7.9 \%$ as of vibration free apparatus and $7.4 \%$ as of fucl piping, and that of fire door was $30.7 \%$ (161/524 bldgs) [17]. Those high rate of damages were also witnessed in other earthquakes.For example,the rate of damage of sprinkler systems was $56 \%$ (38/68 bldgs) in 
San Fernando earthquake (M 6.6) on 9 Feb.,1971[18], and 41\% (18/44 bldgs) in Hachinohe city by the Sanriku Haruka Oki earthquake(M 7.5), Japan,on 28 Dec.,1994, when 30 heads of sprinkler systems effectively exinguished quake-fire on the 2 nd floor in a commercial building with 5 stories and total floor area $3,911 \mathrm{~m}^{2}$ [19]. The rate of damage of expansion joints was $100 \%$ at higher floor level of $5 \sim 10$ th and $65 \%$ of lower floor level, and water pipes or erectric cables poked through fire compartment were mostly in safety by their own flexibility[20]. Earthquake fire experiences have not been seriously revealed in buildings so far,but it seems to be of importance that some appropriate preparedness should be taken into practice,because thehigh rate of damage of fire related equipments must be a symptom of coming tragedy.

TABLE 5. Damage of fire equipments in sprinkler-installed buildings

\begin{tabular}{l|c|c|c|c}
\hline fire equipments & invstgted bldgs. & damaged & non-damaged & remarks \\
\hline sprinkler & 537 & $220(41)$ & $316(58.8)$ & Hachinohe Ct. \\
pomp/ tank & & $44 / 75(8.2 / 14)$ & & sp $=41 \%(18 / 44)$ \\
plumbing/ head & & $135 / 121(25.5 / 22.5)$ & & head $=25 \%$ \\
box & & $18(3.4)$ & & plmbng $=22.7 \%$ \\
hydrant & 443 & $105(23.7)$ & $335(75.6)$ & San Fernando \\
fire alarm & 535 & $109(20.4)$ & $424(79.3)$ & sp = 56\%(38/68) \\
broadcast systm & 472 & $60(12.7)$ & $411(87.1)$ & water damage \\
escape sign & 531 & $94(17.7)$ & $436(82.1)$ & $=41(28 / 68)$ \\
generator & 441 & $70(15.9)$ & $369(83.7)$ & \\
fire door & 518 & $156(30.1)$ & $360(69.5)$ & \\
\hline
\end{tabular}

\section{LESSONS FROM FIRE BY THE KOBE EARTHQUAKE}

Through this earthquake, a great deal of lessons were accumulated concerning building and urban firesafety design,which are as follows.

(1) It is inherent to keep aged houses in safety against seismic attacks for reducing risk of deaths and group fire.

(2) Fire origins were dispersed homogeneously in the area of seismic intensity VII. The main reason seems that some combustible materials were ignited by recovered electric energy.And the timing for recovery must be of importance.

(3) Destruction of densely inhabited districts mixed with chemical shoes factories accelerated spread of group fire, and remodelling of these inner city areas should be one of 
urgent considerations.

(4) Although fire spread at slow speed in the Kobe case,wind must be the most careful factor for restraining group fire.

(5) Open spaces such as park, railway area, river and continuous ow of buildings were effective as fire barrier.

(6) Almost city fire hydrants were useless mainly because of destruction of plumbing systems and cisterns.Besides school pools, old well were helpful beyond expectation.

(7) It is quite important to keep roads functional for emergency activities.

(8) Isolated buildings in fire area were completely burnt up, and the protection of openings by wired glass or fire fighting is iffective for fire stopping.

(9) Highly damaged fire equipments such as sprinkler or emergency generator seems to increase the risk of fire hazards, especially in the daytime.

(10) It is important to keep escape route clear without fire hose scattered down from hyrant or unmovable door deformed by seismic motion.

(11) Failed fire information and observing systems made fire fighting activities difficult. Besides,wireless telephone systems were useful for peoples' urgent communication.

Through considering the above mentioned lessons which are shaped in TABLE 6, there need various sorts of countermeasures to be carried out for developing building firesafety design agaist large earthquakes.

TABLE 6. Lessons from the Kobe Earthquake

\begin{tabular}{l|l}
\hline \multicolumn{1}{c||}{ Lessons } & \multicolumn{1}{c}{ Countermeasures } \\
\hline collape of aged houses & $\begin{array}{l}\text { installation of braces, renewal of old or decayed } \\
\text { houses; fixing of roof tiles (kawara) }\end{array}$ \\
\hline $\begin{array}{l}\text { numbers of fire out- } \\
\text { break }\end{array}$ & $\begin{array}{l}\text { check of the timing of recovered erectric service,and } \\
\text { wiring in old houses; flexibility and blocking of gas }\end{array}$ \\
\hline $\begin{array}{l}\text { occurrence of group } \\
\text { fire }\end{array}$ & $\begin{array}{l}\text { clearance of destroyed houses to keep traffic flow \& } \\
\text { fire fighting smooth,moving of chemical factories, } \\
\text { construction of urban fire compartment,analysis of } \\
\text { frying brands, improvement of imformation systems }\end{array}$ \\
\hline many building fire & $\begin{array}{l}\text { flexibilityof fire equipments (sprinkler,emergency } \\
\text { generator),improvement of hydrant or entrance door } \\
\text { fire management during earthquake }\end{array}$ \\
\hline
\end{tabular}




\section{A CONCEPT ON BUILDING FIRESAFETY DESIGN TO URBAN FIRE PREVENTION}

\section{1) Fire protection of buildings}

The fire in an individual building caused by seismic motion must be taken into consideration.In strong motion,several fires are subject to occur in a building at the same time, and if occurred in the daytime,many people might 'ie fatal.A concept on building firesafety design against large earthquake would be formed according to the following steps, which are also shown in TABLE 7. The first step is to classify the intensity of seismic motions. They are divided into two levels. The intensity level of $\mathrm{V} \sim \mathrm{VI}$ means an earthquake of this level will expect to occur one or two times through the existence of the concerned building, and the level of more than VII: an earthquake of this level will scarecely expect to occur on time through the existence of the concerned building.Thesecond step is to classify buildings which would be divided into 2 types according to theiroccupancy or height.High rise building of over 60 meters means this building will be expected to have no damages of fire related facilities or equipments against intensity level of V $\sim \mathrm{VI}$, and also no damages of main fire related facilities or equipments by intensity level of more than VII. Buildings relating to disaster prevention activities such as city hall, fire orpolice department building, school, hospital and home for handicapped people will be expected no damages of fire facilities or equipments against any seismic intensity level. Privatebuildings or apartment houses will be expected to have no damages of main fire facilities orequipments against any seismic intensity level.

TABLE 7. Procedure of building firesafety design against large earthquake

\begin{tabular}{|c|c|c|}
\hline selection & & contents \\
\hline \multirow{2}{*}{$\begin{array}{l}\text { seismic } \\
\text { intensity }\end{array}$} & $\mathrm{V} \sim \mathrm{VI}$ & one or two times during concerned existence \\
\hline & VII & seldom occurred during concerned existence \\
\hline \multirow[t]{2}{*}{$\begin{array}{l}\text { building } \\
\text { height }\end{array}$} & $\begin{array}{l}\text { highrise } \\
(>60 \mathrm{~m})\end{array}$ & $\begin{array}{l}\text { no damages against } \mathrm{V} \sim \mathrm{VI} \\
\text { no damages of main equipments against VII }\end{array}$ \\
\hline & others & accoiding to usage \\
\hline \multirow[t]{3}{*}{ usage type } & emergency & no damages against VII \\
\hline & other publiq & $\begin{array}{l}\text { no damages against } \mathrm{V} \sim \mathrm{VI} \\
\text { no damages of main equipments against VII }\end{array}$ \\
\hline & private & according to individual policy \\
\hline
\end{tabular}




\section{2) Some details on seismic fire protection}

(1) Protection of escape routes

In an apartment fire, an evacuee could not escape and burnt to death because only one entrance door was fixed and unable to move caused by deformation of the frame,which means a door should be installed free from seismic motion. In other cases,furnitures, household goods,hydrant hose were dispersed on around a hall or corridor,which made difficulties of peoples' evacuation.

(2) Seismic free design for fire equipments

Fire equipments such as sprinkler,emergency generator were damaged with high rate, and if the earthquake occurred in the daytime, it could induce more serious conditions to in-building peoples.Pipes poked through expansion joint were partly damaged.However, they had been safe, if they would have been installed according to the guideline which recommends plumbing should be enough flexible to seimic deformation with the angle of $1 / 200 \sim 1 / 100$ between two floors[23]. As shown in previou TABLE 5,numbers of sprinkler's head were deformed, because of the different movement between head and ceiling tiles.In case of emergency generators, they were unmovable by various reasons such as leakage of cooling water or fuel oil, which indicates their reliability should be considered on the systematic point of view.

(3) Protection of openings

Several buildings were survived by setting some noncombustible materials or splashing water over their windows.Even in these cases, a building behind the others or glazing reinforced by wire were more effective. This means double rows of protected buildings would be useful for fire barriers.

\section{3) Basic concept on fire compartmentation in urban area}

Urban areas are classified here by the following 5 types for the prevention of group fire. And they are shaped in TABLE 8.

(1) Urban area densely inhabited by aged[note.1] or unprotected[note.2] houses or tenements to be encompassed by urban semi-fire compartment[note.3] with the maximum size one ha, which is about equal to $1 / 25$ size of one primary school area, and population will be about 100 [note.4][21]. If encompassed by fire compartment, the maximum size could be doubled. Difference of the performance between fire compartment and semi-fire compartment should be clarified in the future.

(2) Urban area occupied by comparatively new protected houses or tenements to be encompassed by semi-urban fire compartment with the maximun size 5ha.If encompassed by fire compartment, maximum size could be doubled. 
(3) Urban area mixed with buildings and aged or unprotected houses to be encompassed by semi-urban fire compartment with the maximun size 5 ha. If encompassed by fire compartment,maximum size could be doubled.

(4) Urban area mixed with buildings and comparatively new houses to be encompassed by semi-urban fire compartment with the maximun size 10 ha.If encompassed by fire compartment,maximum size could be doubled. If encompassed by fire compartment, maximum size could be doubled.

(5) Urban area occupied by buildings with the maximun size $25 \mathrm{ha}$.

[note.1]

Structural safety texts on the Japan Building Regulation were revised in 1970, when seismic resistivity of traditional houses was improved.

[note.2]

Unprotected means that a house is not covered by fire retardant claddings on exterior wall and roof, and its openings have normal glazing.

[note.3]

- Urban fire compartment could be formed by the combination of open space such as park,primary school ground, broad belt of road,railway area and river more than about $20 \mathrm{~m}$ in width, and double rows of continuous both seismic and fire resistive houses whose exterior wall has no confronted openings, and if not, each opening protected by fire door or wired glazing.

- Semi urban fire compartment could be formed by the combination of open space in about half size of primary school ground,broad belt more than $10 \mathrm{~m}$ in width,and continuous seismic resistive and fire protective houses with no confronted openings, and if not,each opening protected by fire door or wired glazing. [note.4]

The values of burnt down areas with more than 1 ha by the Kobe earthquake were 14.2/9.4/8.9/7.5/7.2/5.7/2.9/2.4/2.0/1.2 ina,respectively[9].

TABLE 8. A basic concept on urban fire compartmentation

\begin{tabular}{|c|c|c|c|c|c|}
\hline components & compartment & max.size & components & compartment & max.size \\
\hline aged+unprtcted & semi-fc & (1) 2 & aged+unprtcted & semi-fc & (4) 5 \\
\hline hous+tnment & fc & ( 2 ) 4 & hous + tnmnt + bldg & fc & ( 8$) 10$ \\
\hline new+protected & semi-fc & (4) 5 & new+protected & semi-fc & $(10) 20$ \\
\hline hous+tnmnent & fc & $(8) 10$ & hous+tnmnt+bldg & fc & (20)25 \\
\hline building & not required & 25 & highrise bldg & not required & $\infty$ \\
\hline
\end{tabular}




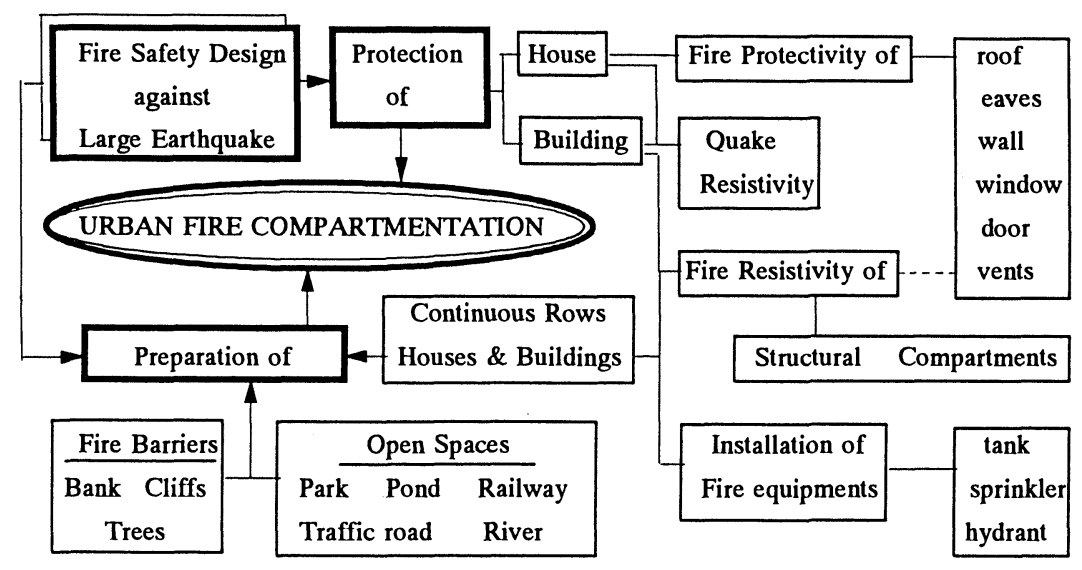

FIGURE 7. Composition of urban fire compartmentation

\section{4) Improvement or construction of emergency information systems}

One of the main causes of occurrence of group fire was induced in the chaos of initial fire informations.For instance,remote controlled cameras set on the top of buildings, failed just after the strong motion,because of erectric interruption[22]. Remote sensing must be necessary for fire fighting.In the future, fire activities will be performed on a vertual reality stage or cyberspace. Technology on creating cyberspace will be one of the most interesting and important subjects. Fire control is carried out at the fire management center, where in general unable to see a real fire, and what should be 'reality' in a screen image or human brains might be indispensable for elevating the quality of firesafety design.

\section{5) Improvement of city gas and water supply systems}

One of the most important issues was focused on the fire resistivity of city gas supply systems. Combination of gas leakage with return supply of erectric power seemed to make an outbreak of fire, which means that gas piping should be flexible especially at the inducing point into a house or building, and blocking of piping networks is indispensable for the reduction of gas disaster. And almost city water services were interupted, because of destruction of a reservoir and strait piping systems, which means also that it is quite important to grade up the seismic resistivity of reservior and to make piping systems pararell. Other systems by using sea or deep underground water might have been useful for the Kobe case. 


\section{CONCLUSION}

Building firesafety designs against great earthquake are classified into three types,which are for the fire prevention of urban, house and building. Urban fire could be conquered by encompassing inner-city areas by urban fire compartment. There exist serious problems on aged houses, and they sould be urgently improved to secure both seismic and fire safety. On the other hand,recent houses are witnessed to be reliable against earthquake, but as for fire safety, if they are surrounded by grouped fire, they are only tenable with open spaces or fire fighting activities.Building were revealed its fragility, because fire equipments were considerably damaged.The Kobe-Hanshin case needs another stride of fire science and technology.

\section{REFERENCES}

1. The Department of Seismic and Volcano,the Japan Meteorological Agency;'Outline on earthquake and volucano activities,Jan.,1995.

2. Ministry of Health and Welfare;Analysis on deaths caused by the Great Hanshin Earthquake,Dec., 1995.

3. Fire Defense Agency;Records on the Great Hanshin-Awazi Earthquake,Jan.,1996.

4. Japan Academic Council; Arrangement of emergent medical care systems for victims mitigation,Oct.,1995.

5. Hayashi H.;'Mental care after disaster', Self defense against disaster, No.129,p6-8, The Tokyo Disaster Prevention and Insutruction Association,Jan.,1996.

6. Kyodo Tsushin News; 'Kobe City recognized the number of fatalities reached 4,319 including 422 deaths related to earthquake disaster.',July 14,1995

7. Building Research Institute; The final report of investigation on the ' 96 Hyogoken Nambu eartquake damages,Mar.,1996.

8. Suzuki K.and Matsubara Y.; Fire outbreaks for 10 days after the Hyogoken Nambu earthquake,Report of Fire Research Institute No.49,1996.

9. Kobe Fire Department;Outline of the Great Hanshin-Awazi earthquake fire,April,1996.

10. Sekizawa A.;Facts on fire outbreaks at the Kobe-Hanshin earthquakes, Proceedings of annual meeting of AIJ,Sep.,1996.

11. Building Reasearch Institute; Interium report on the investigation of damages during the Hyogoken Nambu earthquake,Aug.,1995.

12. Murozaki M.;'Research on earthquake fire in the Great Hanshin-Awazi earthquake',Proceeding of Kinki-branch meeting No.35,May,1995.

13. Kumagai Y.;Panel disccussion materials $(\cdots$ large urban fire and its countermeasures, the Japan Association for Fire Science and Engineering,Jan.,1996.

14. Fire Research Institute; Quick report on large urban fires in Kobe city duriung the Hyo 
goken Nambu earthquake,Mar.,1995.

15. Sugahara S. and Kidera K.; Investigation on damage of housing windows in the Hyogo ken Nambu earthquake,Oct.,1995.

16. The Association of Building Materials Industries; Investigation on damages of housing materials by the Hyogoken Nambu earthquake,Oct.,1995.

17. Kobe Fire Department; An investigation on damage of fire equipments caused by the Hyogoken Nambu earthquake,Sep.,1995.

18. Pacific Fire Rating Bureau;San Fernando Earthquake,Feb.,1971.

19. Hachinohe City-Ambient Muninshiparities Fire Department and Disaster Insurance Association; Investigation on damage of fire equipments in the Sanriku Haruka Oki earthquake,1996.

20. Tsukahara and Sugahara S.; investigation of damage of erectric cable and expansion joint by Hyogoken Nambu earthquake,p3083-3084, ransaction of annual meeting of Architectural Institute of Japan,Aug.,1995.

21. Morimura M.;'Environmental arrangement planning in urban design',p1975-1980,Building planing guide-book',Architural Institute of Japan,Feb.,1980.

22. Japan Fire Association; 'Damages of fire telecommunication facilities', Record on the Great Hanshin-Awazi earthquake,p94,March,1996.

23. Building Center of Japan;'Plumbing methods for piping pass through fire compartment', p56-57,Guideline for securing earthquake resistivity of building equipments,March,1995. 